\title{
Analysis of gene expression in the bovine corpus luteum through generation and characterisation of $960 \mathrm{ESTs}^{\text {th }}$
}

\author{
Orla M. Casey $^{\mathrm{a}, \mathrm{b}}$, Richard Fitzpatrick ${ }^{\mathrm{a}, *}$, James O. McInerney ${ }^{\mathrm{c}}$, Dermot G. Morris ${ }^{\mathrm{a}}$, \\ Richard Powell ${ }^{\mathrm{b}}$, Joseph M. Sreenan ${ }^{\mathrm{a}}$ \\ a Animal Reproduction Department, Teagasc, Agriculture and Food Development Authority, Athenry, Galway, Ireland \\ ${ }^{\mathrm{b}}$ Department of Microbiology, National University of Ireland, Galway, Ireland \\ ${ }^{\mathrm{c}}$ Department of Biology, National University of Ireland, Maynooth, Ireland
}

Received 23 December 2003; received in revised form 11 March 2004; accepted 24 March 2004

Available online 10 May 2004

\begin{abstract}
To gain new insights into gene identity and gene expression in the bovine corpus luteum (CL) a directionally cloned CL cDNA library was constructed, screened with a total CL cDNA probe and clones representing abundant and rare mRNA transcripts isolated. The $5^{\prime}$ terminal DNA sequence of 960 cDNA clones, composed of 192 abundant and 768 rare mRNA transcripts was determined and clustered into 351 non-redundant expressed sequence tag (EST) groups. Bioinformatic analysis revealed that 309 (88\%) of the ESTs showed significant homology to existing sequences in the protein and nucleotide public databases. Several previously unidentified bovine genes encoding proteins associated with key aspects of CL function including extracellular matrix remodelling, lipid metabolism/steroid biosynthesis and apoptosis, were identified. Forty-two (12\%) of the ESTs showed homology with human or with other uncharacterised ESTs, some of these were abundantly expressed and may therefore play an important role in primary CL function. Tissue-specificity and temporal CL gene expression of selected clones previously unidentified in bovine CL tissue was also examined. The most interesting finds indicated that mRNA encoding squalene epoxidase was constitutively expressed in CL tissue throughout the oestrous cycle and 7-fold down-regulated $(P<0.05)$ in late luteal tissue, concomitant with the disappearance of systemic progesterone, suggesting that de novo cholesterol biosynthesis plays an important role in steroidogenesis. The mRNA encoding the growth factor, insulin-like growth factor-binding protein-related protein 1 (IGFBP-rP1), remained constant during the oestrous cycle and was 1.8 -fold up-regulated $(P<0.05)$ in late luteal tissue implying a role in CL regression.
\end{abstract}

(C) 2004 Elsevier B.V. All rights reserved.

Keywords: Bovine (Bos taurus); Corpus luteum; Expressed sequence tag; Bioinformatics; Northern blot

\section{Introduction}

The corpus luteum (CL) is an important mammalian reproductive organ producing progesterone which plays a central role in regulation of the oestrous cycle and in the establishment and maintenance of pregnancy [1]. The CL develops from the dominant ovarian follicle after ovulation and comprises steroidogenic (theca and granulosa-lutein) and non-steroidogenic (endothelial, immune, fibroblasts)

\footnotetext{
is Supplementary data associated with this article can be found, in the online version, at doi:10.1016/j.bbaexp.2004.03.011

* Corresponding author. Tel.: +353-91-845849; fax: +353-91-845847.

E-mail address: rfitzpatrick@athenry.teagasc.ie (R. Fitzpatrick).
}

cells, both of which are essential for the synthesis and secretion of steroids. The bovine CL is a transient organ with an average lifetime of approximately 17-18 days and undergoes extreme change throughout its life span in terms of size, structure and function [2,3]. The fate of the CL is principally determined by either the luteolytic action of uterine produced prostaglandin F $2 \alpha$ (PGF2 $\alpha$ ), which induces regression of the $\mathrm{CL}$ [4] or the luteotrophic action of anterior pituitary produced luteinizing hormone (LH), which is responsible for the maintenance and steroidogenic activity of the CL [5]. In addition, there is growing evidence implicating the IGF system, angiogenic factors and immune cells in the development, maintenance and regression of the CL $[6,7]$. 
The primary function of the CL is steroid hormone synthesis, in particular progesterone production. Systemic progesterone concentrations during the oestrous cycle are the result of changes in luteal blood flow, the size and number of steroidogenic cells [8] and alterations in gene expression for key enzymes involved in steroidogenesis $[5,9]$. Progesterone plays a key role in the endocrine control of the oestrous cycle through its negative feedback effects on the hypothalamic release of gonadotrophin releasing hormone and consequently LH secretion. Progesterone also plays a critical role in the establishment and maintenance of pregnancy by promoting and/or controlling the secretion of uterine derived proteins and growth factors, the growth rate of the embryo and embryonic secretion of interferon-tau [10]. Furthermore, several studies have reported a positive relationship between early luteal phase systemic progesterone and embryo development $[10,11]$ and embryo survival in cows $[11,12]$.

Despite the interest and essential role of the CL in animal reproduction, relatively little information is available on CL genes with less than 140 annotated CL nucleotide sequences currently deposited in the international DNA databases. This lack of knowledge represents a major obstacle hampering an improved understanding of the molecular mechanisms controlling CL development and regression and the variations in systemic progesterone concentrations. The identification and characterisation of genes involved in key aspects of CL function is an important first step towards a broader understanding of CL biology and this has potential implications for the longterm development of new methodologies for regulation of the oestrous cycle and enhancing animal fertility. Expressed sequence tag (EST) analysis of gene expression in specific tissues is widely used to characterise gene function and tissue physiology [13]. This approach has been used to accelerate gene discovery in a variety of bovine tissues including the ovary [14], mammary gland [15], embryo [16], foetus [17], and multiple tissues [18]. In addition, a recent study reported the identification and mapping of 11 gene sequences preferentially expressed in the bovine CL [19]. The generation of ESTs is vital to the growing area of bovine functional genomics and in facilitating large-scale gene expression studies [20,21], gene mapping, and the identification of genes influencing economically important traits $[22,23]$. In this paper, we describe the generation and characterisation of 351 unique CL ESTs comprising 38 abundant and 313 rare mRNA transcripts. These ESTs were classified according to their expression levels and grouped into 15 functional categories. Tissue-specificity and temporal CL gene expression of selected clones encoding transcripts involved in apoptosis (death-associated protein 5, DAP5), cholesterol biosynthesis (squalene epoxidase), cellular proliferation (insulin-like growth factor-binding protein-related protein 1, IGFBP-rP1) and an uncharacterised EST was also determined using RT-PCR and Northern analysis.

\section{Materials and methods}

\section{1. cDNA library construction and quality analysis}

Corpus luteum tissue was collected from heifers immediately after slaughter at days $6(n=3), 8(n=3)$, and 14 $(n=3)$ of the oestrous cycle and immediately frozen in liquid nitrogen and stored at $-80{ }^{\circ} \mathrm{C}$. Total RNA was prepared from fragmented frozen tissue using the TRIzol reagent (Gibco BRL Life Technologies Ltd., Renfrewshire, UK). RNA integrity was assessed by examining the $28 \mathrm{~S}$ and 18S ribosomal RNA bands on ethidium bromide stained 1\% agarose gels [24]. Total RNA was then pooled and enriched for messenger RNA (mRNA) using the Oligotex mRNA midi kit (Qiagen Ltd., Crawley, UK). Total RNA and mRNA quantity was determined by absorbance at $260 \mathrm{~nm}$ and the degree of protein contamination was assessed by the ratio of absorbance at 260 and $280 \mathrm{~nm}$. The cDNA library was constructed using the $\lambda$ ZAP cDNA synthesis/gigapack III gold cloning kit (Stratagene cloning systems). cDNA synthesis was performed using $5 \mu \mathrm{g}$ of mRNA and oligo$(\mathrm{dT})_{18}$ primer and used to generate a directionally cloned cDNA library according to manufacturer's instructions. The library was then amplified and stored at 4 and $-80{ }^{\circ} \mathrm{C}$ in $7 \%$ DMSO for long-term storage.

The background of parental $\lambda$ Zap Express pfu was established by plating on soft top agar containing $3.2 \mathrm{mg} /$ $\mathrm{ml} \mathrm{XGal} \mathrm{and} 1 \mathrm{mM}$ IPTG. Average cDNA clone length was established after in vivo excision of 12 random clones into pBK-CMV phagemid form according to manufacturers' (Stratagene) instructions. Excised clones were grown overnight in LB containing kanamycin $(50 \mu \mathrm{g} / \mathrm{ml})$ and phagemid DNA was prepared from $3 \mathrm{ml}$ of overnight bacterial culture using a High Pure Plasmid Isolation Kit (Roche Diagnostics $\mathrm{GmbH}$, Mannheim, Germany). The cloned cDNA inserts were released by digestion with the restriction enzymes $P_{s t} \mathrm{I}$ and $X b a \mathrm{I}$ and analysed by electrophoresis through $1 \%$ agarose gels. The size of the cloned cDNA fragments were determined by visual comparison to $\lambda$ HindIII molecular weight markers (New England Biolabs, MA, USA) and 100 bp ladder (Amersham Pharmacia Biotech, NJ, USA).

\subsection{Screening of $C L c D N A$ library with total $c D N A$ probe}

The selection of abundant and rare mRNA encoding cDNA clones was carried out essentially as described previously [25]. Briefly, approximately 3000-4000 phage from the CL cDNA library were screened with a total cDNA probe. The cDNA probe was generated by reverse transcription of $5 \mu \mathrm{g}$ of pooled total RNA isolated from days 6,8 and $14 \mathrm{CL}$ tissue using a mixture of anchored oligo-(dT) $)_{12}$ primers (Sigma Genosys, Cambridgeshire, UK) and $1 \mu \mathrm{l}$ of $6000 \mathrm{Ci} / \mathrm{mmol}^{2} \alpha^{32} \mathrm{P} \mathrm{dCTP}$. The reverse transcription was performed at $37{ }^{\circ} \mathrm{C}$ for $30 \mathrm{~min}$ before the addition of $2 \mu \mathrm{l}$ of $2.5 \mathrm{mM}$ dNTP and incubated at $37^{\circ} \mathrm{C}$ for a further $30 \mathrm{~min}$. The cDNA probe was purified using the High Pure PCR 
Product Purification Kit (Roche Diagnostics) and hybridisation was carried out as previously described [24]. Following autoradiography at $-70{ }^{\circ} \mathrm{C}$, hybridisation-positive and negative plaques representing abundant and rare mRNA encoding cDNA clones, respectively, were catalogued and stored separately at $4{ }^{\circ} \mathrm{C}$.

\subsection{DNA sequencing and bioinformatic analysis}

Single-pass sequencing of the $5^{\prime}$-termini of 960 selected CL cDNA clones in phagemid form was performed using the ABI 3700 automatic DNA sequencer (PE Applied Biosystems, CA, USA) and the ABI prism Big Dye Terminator Cycle Sequencing Ready Reaction kit (PE Applied Biosystems). After elimination of vector sequences, and ESTs $<300$ $\mathrm{bp}, 841$ ESTs were included for further analysis. These were subjected to cluster analysis to remove EST redundancy and resulted in 351 unique ESTs. The longest EST was taken as the unique representative member of each EST cluster. All unique ESTs were submitted to the NCBI nr protein database using the BLASTX [26] program located on the NCBI BLAST homepage http://www.ncbi.nim.nih.gov/BLAST/). Sequences which did not have a significant match were then submitted to GenBank nucleotide databases using the BLASTN [26] program located on the Pole Bio-informatique Lyonnais homepage http://pbil.univ-lyon1.fr/). In both cases putative identification was assigned to sequences with an expectation value $<1 \mathrm{e}^{-7}$. All unique ESTs have been deposited in GenBank dbEST under accession numbers, BU917059 BU917082, BU917084 BU917091, BU917095 BU917154, BU917156 BU917166, BU917168 BU917173, BU917175 BU917193, BU917195 BU917229, BU917231 BU917272, BU917274 BU917286, BU917288, BU917290 BU917337, BU917339 BU917422, CB690962 CB690964.

\subsection{RT-PCR analysis}

Total RNA was extracted from various bovine tissues (kidney, liver, heart, muscle, lung, spleen, oviduct, uterus, ovarian cortex, corpus luteum) using the Trizol reagent (Gibco BRL) as described above. For RT-PCR analysis, samples were treated with RNase-free DNase (Gibco BRL) for $15 \mathrm{~min}$ at room temperature. The reaction was stopped by the addition of $25 \mathrm{mM}$ EDTA and heating to $65{ }^{\circ} \mathrm{C}$ for 10 min. One microgram of total RNA was reverse-transcribed using M-MLV reverse transcriptase (Promega, WI, USA) and $500 \mathrm{ng}$ of oligo-(dT) $)_{15}$ in a $21 \mu \mathrm{l}$ reaction. Four-microliter aliquots from the first-strand cDNA synthesis reaction were then amplified in a $100 \mu \mathrm{l}$ volume containing $1 \times \mathrm{PCR}$ buffer, $0.2 \mu \mathrm{M}$ dNTP mixture, $1.5 \mathrm{mM} \mathrm{MgCl}_{2}, 100 \mathrm{ng}$ of each primer and 2.5 U of Taq DNA Polymerase (Promega). Thirty-five cycles of PCR consisting of $94{ }^{\circ} \mathrm{C}$ for $30 \mathrm{~s}, 54{ }^{\circ} \mathrm{C}$ for $30 \mathrm{~s}$ and $72{ }^{\circ} \mathrm{C}$ for $1 \mathrm{~min}$ were performed. Non-reversetranscribed total RNA was included as a control for the presence of genomic DNA contaminants. Gels were stained with ethidium bromide and visualised using a Molecular
Imager FX (Bio-Rad). Sequences of gene-specific primers used in this study are available on request. The identity of the RT-PCR products was confirmed by DNA sequencing.

\subsection{Northern analysis}

Following twice daily checks for the occurrence of oestrus (day 0), corpus luteum tissue was obtained from heifers $(n=3)$ at day $6,8,14$, and 17 of the oestrous cycle. In all cases, morphological dating of CL tissue was used to confirm the luteal phase classification [27], and in addition the functional status of the isolated CLs was determined by measurement of systemic progesterone concentration using RIA (Coat-a-Count, Diagnostic Products Corporation, USA). Plasma progesterone concentrations were within a range (mean \pm SEM) of $6.5 \pm 0.42 \mathrm{ng} / \mathrm{ml}$, to $7.3 \pm 1.5 \mathrm{ng} / \mathrm{ml}$ confirming that the days 6,8 and 14 CLs were functional. Plasma progesterone concentration of $0.4 \pm 0.12 \mathrm{ng} / \mathrm{ml}$ confirmed that the day 17 CLs had regressed. For Northern analysis total RNA $(20 \mu \mathrm{g})$ was size fractionated through a denaturing $2.2 \mathrm{M}$ formaldehyde $1 \%$ agarose gel in $1 \times$ MOPS buffer, transferred to nylon membranes (Schleicher \& Schuell, Dassel, Germany) and baked at $80{ }^{\circ} \mathrm{C}$ for $2 \mathrm{~h}$. Membranes were prehybridised for $4 \mathrm{~h}$ at $42^{\circ} \mathrm{C}$ in $15 \mathrm{ml}$ of Ultrahyb solution (Ambion Europe Ltd.) followed by overnight hybridisation at $42{ }^{\circ} \mathrm{C}$ with ${ }^{32} \mathrm{P}$-radiolabelled DNA fragments encoding DAP5, squalene epoxidase, IGFBP-rP1 and an abundantly expressed EST accession no. BU917379. DNA probes were generated using Strip-EZ DNA kit (Ambion) according to manufacturer's instructions. A control hybridisation using a ${ }^{32} \mathrm{P}$-radiolabelled DNA fragment of the $18 \mathrm{~S}$ rRNA was carried out to normalize for RNA loading. Membranes were washed twice for $5 \mathrm{~min}$ in $2 \times \mathrm{SSC}, 0.1 \%$ SDS at $42{ }^{\circ} \mathrm{C}$ and twice for $15 \mathrm{~min}$ in $0.1 \times$ SCC, $0.1 \%$ SDS at $42{ }^{\circ} \mathrm{C}$. Membranes were exposed to imaging plates (Fugi, BAS-MS) and scanned using a Molecular Imager FX (BioRad). Densitometry data were examined by analysis of variance using PROC GLM, SAS [28].

\section{Results and discussion}

\section{1. cDNA library construction and quality assessment}

The CL cDNA library contained $3.2 \times 10^{4}$ primary transformants with an average insert size of $2.3 \mathrm{~kb}$ and a parental background of $<2 \%$. Analysis of 12 randomly chosen clones indicated a range of cDNA insert sizes from 1.3 to $4.5 \mathrm{~kb}$. Since all clones were $>500 \mathrm{bp}$ in length, it was not necessary to remove short-length clones prior to sequencing.

\subsection{Selection of abundant and rare $m R N A$ encoding $c D N A$ clones}

Several thousand cDNA clones were screened by in situ hybridisation with a total $\mathrm{CL}$ cDNA probe in order to 
identify abundant and rare encoded mRNA transcripts. Clones exhibiting either a positive or negative hybridisation signal were catalogued as representing either abundant or rare mRNA encoding cDNA clones, respectively. The resolving power of this type of probe is estimated to detect cDNA clones derived from mRNA transcripts that exceed $0.06 \%$ of the total mRNA population [29]. Hybridisation of complex probes to cDNAs has been used to identify abundantly expressed clones and reduce gene redundancy in conventional cDNA libraries [21,30]. This differential screening technique has also been incorporated into several EST surveys providing informative qualitative gene expression data by identifying cDNA clones exhibiting high and low expression levels $[25,31,32]$. In this study, $14 \%$ of the clones hybridised with the total cDNA probe and were catalogued as abundant, whereas the remaining $86 \%$ nonhybridising clones were catalogued as rare mRNA transcripts. Significantly, $47 \%$ of the clones catalogued as lowly expressed, represented distinctly different clones compared to $21 \%$ of the abundantly expressed clones.

\subsection{EST sequencing and bioinformatic analysis}

Nine hundred and sixty randomly chosen cDNA clones composed of 192 abundant and 768 rare encoding mRNAs were submitted to single-pass $5^{\prime}$-terminal DNA sequencing. Following elimination of vector sequences, only ESTs $>300$ bp were accepted for bioinformatic analysis. Cluster analysis was then performed using the criterion that ESTs with $<1 \%$ nucleotide mismatch over 300 nucleotides were derived from the same mRNA transcript. From this analysis, 351 unique ESTs were identified (derived from 160 clusters and 191 singletons), and consisted of 38 abundant and 313 rare encoding mRNA transcripts (Table 1).

The 351 unique bovine CL ESTs were translated into all six reading frames and used to search for amino acid homology in the NCBI nr protein database. Two hundred and forty-four $(70 \%)$ of the ESTs showed significant similarity to previously identified protein sequences. The

Table 1

Summary of CL EST analysis

\begin{tabular}{llll}
\hline Bioinformatic analysis & $\begin{array}{l}\text { CL EST } \\
\text { number }\end{array}$ & $\begin{array}{l}\text { Abundant } \\
\text { mRNA } \\
\text { class }\end{array}$ & $\begin{array}{l}\text { Rare } \\
\text { mRNA } \\
\text { class }\end{array}$ \\
\hline $\begin{array}{l}\text { Total number of 5' } \\
\text { EST sequences }\end{array}$ & 960 & 192 & 768 \\
$\begin{array}{l}\text { Number of remaining } \\
\text { ESTs }\end{array}$ & 841 & 182 & 659 \\
$\begin{array}{l}\text { Unique ESTs } \\
\text { Protein database match }\end{array}$ & 244 & 38 & 313 \\
$\begin{array}{l}\text { Nucleotide match } \\
\text { (excluding dbEST) }^{\text {b }}\end{array}$ & 65 & 24 & 220 \\
EST match $^{\text {b }}$ & 451 & 8 & 57 \\
\hline
\end{tabular}

${ }^{\text {a }}$ Bovine CL ESTs $>300$ bp following elimination of vector sequence.

${ }^{\mathrm{b}}$ Putative identification was assigned to sequences with an $E$-value $<1$ $\mathrm{e}^{-7}$. remaining 107 ESTs were submitted to the GenBank nucleotide databases. A total of $65(18 \%)$ of the ESTs showed homology to nucleotide gene sequences, while $42(12 \%)$ matched sequences in dbEST (Table 1). Overall, of the 351 unique ESTs analysed, 34\% were identical or almost identical to known bovine sequences and $66 \%$ matched human or other sequences. All ESTs have been assigned accession numbers and deposited in the public GenBank database.

\subsection{Abundantly expressed CL ESTS}

Several of the 38 abundant ESTs encoded proteins involved in specific aspects of CL function including progesterone biosynthesis (apolipoprotein $\mathrm{A} 1$ and StAR), apoptosis (DAP5) and angiogenesis (CTGF). Two of the abundantly expressed ESTs were homologous with human zinc finger proteins. Zinc fingers are structural motifs shared by nuclear receptors such as steroid hormone receptors, and other DNA binding proteins [33]. Typically, these proteins regulate transcription and it is this characteristic that makes these clones candidates for gene regulation in the CL. Six of the abundantly expressed ESTs had homology to previously isolated bovine, human and swine ESTs. The isolation of highly expressed ESTs with no annotated biological function is potentially an important find since abundantly expressed genes are likely to have a key role in tissue function.

\subsection{Classification of CL ESTS}

Of the 351 ESTs, 161 were classified according to Adams et al. [34] and by subjective comparison with genes of recognised function and grouped into 15 functional categories. The results are summarised in Table 2 . Additional information including accession number, abbreviated description, best matching sequence, $E$-value, percent identity, and relative expression level, are provided on a web accessible database http://bioinf.may.ie/Bovine/ bovine_CL_ests.pdf). The results show that genes associated with key aspects of CL function were well represented. For example 45 of the 161 ESTs were linked to apoptosis, extracellular matrix proteins/angiogenesis, growth factors/cytokines, immune response and lipid metabolism/steroid biosynthesis.

Progesterone production is a major function of the $\mathrm{CL}$ and therefore category VIII, which identifies 12 different genes involved in lipid and steroid metabolism is of particular interest. This category includes genes known to be directly involved in key aspects of progesterone biosynthesis, viz., 3 beta-hydroxysteroid dehydrogenase, p450 side chain cleavage enzyme, and steroidogenic acute regulatory protein (StAR) which catalyses the rate-limiting step in progesterone biosynthesis [35]. Several ESTs encoded proteins involved in cholesterol uptake including apolipoprotein A1 and the HDL scavenger receptor SR-BI protein. Two enzymes previously uncharacterised in bovine CL tissue, squalene epoxidase and farnesyl-diphosphate farnesyl transferase (squalene syn- 
Table 2

Classification of CL ESTs

\begin{tabular}{|c|c|c|c|c|}
\hline Category & Description & $\begin{array}{l}\text { Number } \\
\text { of unique } \\
\text { ESTs }\end{array}$ & $\begin{array}{l}\text { Abundant } \\
\text { ESTs }\end{array}$ & $\begin{array}{l}\text { Rare } \\
\text { ESTs }\end{array}$ \\
\hline I & apoptosis & 8 & 1 & 7 \\
\hline II & $\begin{array}{l}\text { extracellular matrix } \\
\text { proteins/angiogenesis }\end{array}$ & 9 & 2 & 7 \\
\hline III & cell cycle & 3 & 0 & 3 \\
\hline IV & cell structure & 16 & 3 & 13 \\
\hline $\mathrm{V}$ & $\begin{array}{l}\text { growth factors/binding } \\
\text { proteins/cytokines }\end{array}$ & 7 & 1 & 6 \\
\hline VI & immune response & 4 & 1 & 3 \\
\hline VII & general metabolism & 11 & 0 & 11 \\
\hline VIII & $\begin{array}{l}\text { lipid metabolism/ } \\
\text { steroid biosynthesis }\end{array}$ & 17 & 3 & 14 \\
\hline IX & mitochondrion & 18 & 2 & 16 \\
\hline $\mathrm{X}$ & RNA processing & 7 & 3 & 4 \\
\hline XI & transcription & 13 & 2 & 11 \\
\hline XII & protein synthesis & 10 & 1 & 9 \\
\hline XIII & ribosomal proteins & 24 & 3 & 21 \\
\hline XIV & DNA structure/repair & 5 & 0 & 5 \\
\hline XV & $\begin{array}{l}\text { cell signalling/ } \\
\text { communication }\end{array}$ & 9 & 0 & 9 \\
\hline \multirow[t]{5}{*}{ XVI } & miscellaneous & 102 & 9 & 93 \\
\hline & Total & 263 & 31 & 232 \\
\hline & $\begin{array}{l}\text { Uncharacterised protein/ } \\
\text { nucleotide matches }\end{array}$ & 46 & 1 & 45 \\
\hline & EST matches & 42 & 6 & 36 \\
\hline & Overall total & 351 & 38 & 313 \\
\hline
\end{tabular}

thase), were also identified. Both of these enzymes are involved in de novo cholesterol biosynthesis and their presence suggests that this anabolic pathway is a potential source of cholesterol for progesterone biosynthesis in the bovine CL.

The rapid cyclical changes in luteal growth and regression demands corresponding rapid changes in gene expression and gene regulation. The identification of 13 different ESTs encoding transcriptional regulators provides new insights into the possible processes controlling CL gene expression. This group contains the CCCTC binding factor (CTCF), a highly conserved zinc finger protein, implicated in both transcriptional enhancement and silencing of a diverse set of genes [36]. A cDNA encoding a cofactor required for $\mathrm{Sp} 1$ transcription activation was also identified. Significantly, Sp1 is known to interact with transcription factors that regulate the expression of genes involved in steroidogenesis including StAR [9].

Programmed cell death or apoptosis is responsible for the structural regression and demise of the bovine CL [37]. Category I lists the identity of seven different genes involved in apoptosis, five of which have not been previously identified in bovine. Included in this group is DAP5, which was found to be abundantly expressed and is known to be involved in interferon gamma-induced apoptosis in human neuroblastoma cells [38]. In addition, cDNA clones encoding the antioxidant related genes, manganous superoxide dismutase and catalase, which are known to attenuate the toxic effects of reactive oxygen species, and thwart the onset of luteolysis [35] were also identified.
This CL gene survey also identified cDNA clones encoding the IGFBP-rP1 and three different cytokines. The isolation of these genes supports growing evidence implicating the IGF system and immune cells in the development, maintenance and regression of the CL $[6,7,39]$. Several ESTs were found to encode proteins associated with angiogenesis and extracellular matrix remodelling including SPARC, TIMP2, thrombospondin 1 and the growth factor CTGF. The presence of such proteins is consistent with the dramatic changes in cellular proliferation, differentiation, and tissue remodelling which the CL undergoes during its life span.

\subsection{Expression analysis}

Four cDNA clones were selected for expression analysis and included mRNAs involved in apoptosis (DAP5), cholesterol biosynthesis (squalene epoxidase), cellular proliferation (IGFBP-rP1), and an abundantly expressed EST, accession no. BU917379 whose ortholog was recently isolated from porcine pituitary tissue http://pigest.genome. iastate.edu/). The results of RT-PCR analysis indicated the four clones were expressed in all tissues examined (Fig. 1). Northern analysis indicated that DAP5 and the EST clone were constitutively expressed in CL tissue throughout the oestrous cycle and showed no significant difference in expression between days $(P>0.05)$ (Fig. 2). The constitutive expression of DAP5 in CL tissue suggests that its function is not exclusive to apoptosis. Squalene epoxidase catalyses the conversion of squalene to 2,3(S)-oxidosqualene a rate-limiting step in de novo synthesis of cholesterol [40]. The mRNA encoding squalene epoxidase was found to be expressed in CL tissue throughout the oestrous cycle and 7-fold downregulated $(P<0.05)$ in day 17 regressed luteal tissue, concomitant with the disappearance of systemic progesterone

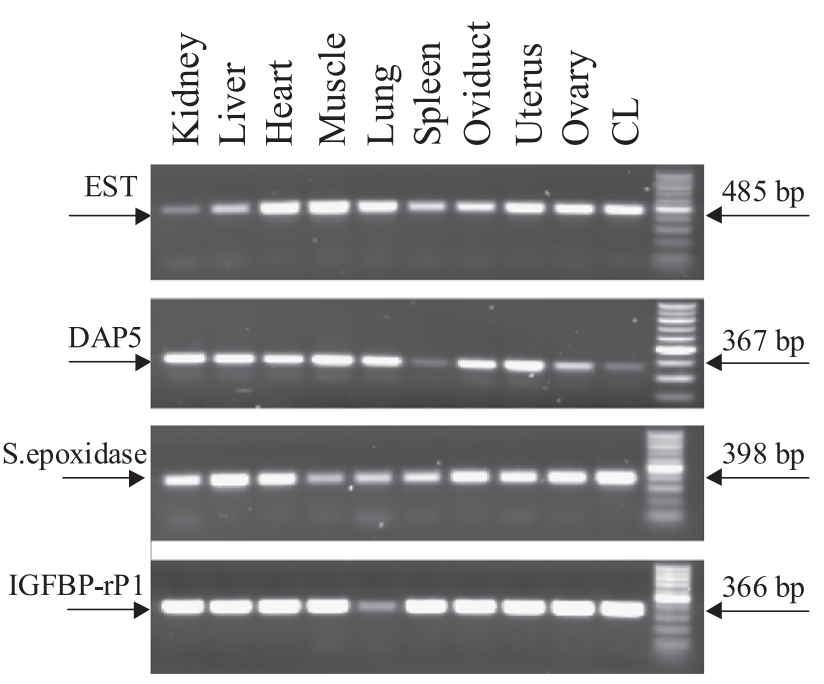

Fig. 1. Tissue distribution of EST clone BU917379, DAP5, squalene epoxidase and IGFBP-rP1 using RT-PCR. The expected size of the RT-PCR products is shown on the right. 
EST BU917379

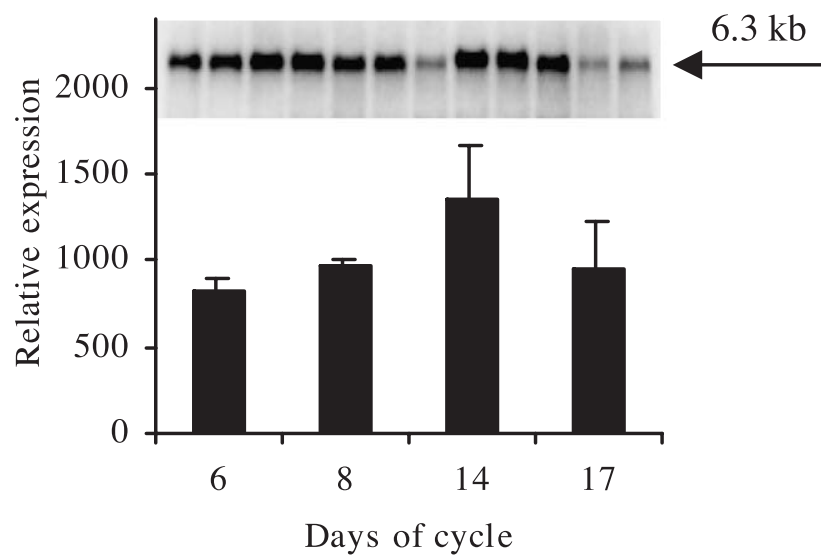

Squalene epoxidase

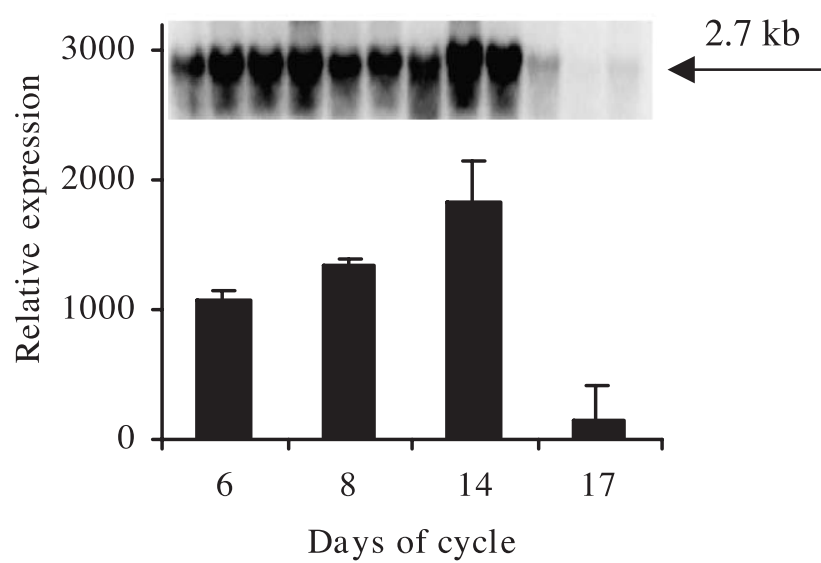

DAP5

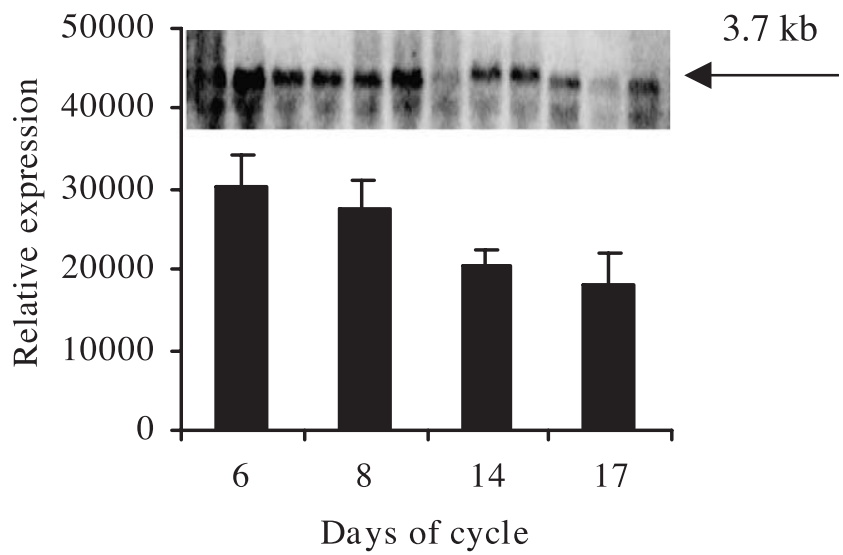

IGFBP-rP1

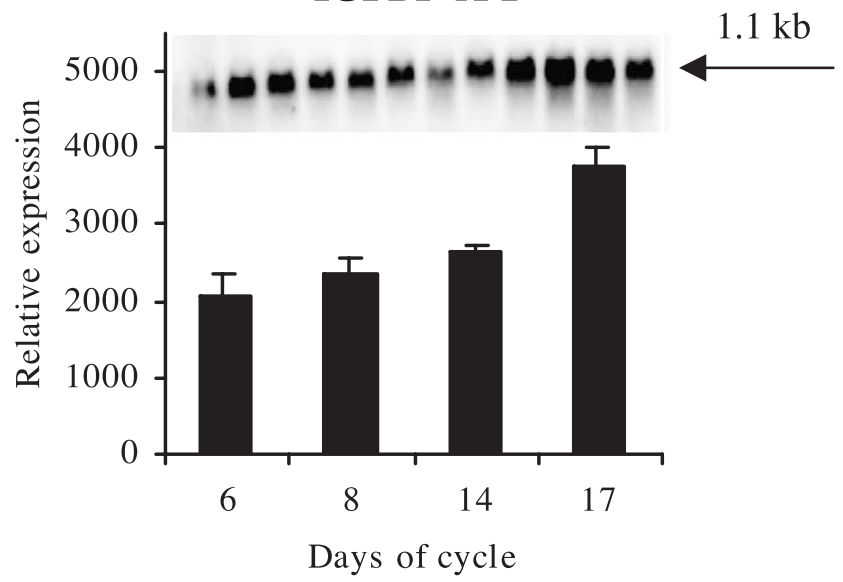

Fig. 2. Temporal expression of EST clone BU917379, DAP5, squalene epoxidase and IGFBP-rP1 in days 6 , 8 , 14 and 17 luteal tissue using Northern blot analysis. The estimated size of the mRNA transcripts is indicated.

(Fig. 2). Cholesterol is an essential precursor in progesterone biosynthesis and is typically obtained from circulating lipoproteins [35]. However, the expression of squalene epoxidase in days 6,8 and 14 luteal tissue suggests de novo cholesterol biosynthesis may also have an important role in steroidogenesis. There is increasing evidence that insulinlike growth factors and their binding proteins are important effectors of luteal function $[41,42]$. In this study, temporal CL gene expression of mRNA encoding IGFBP-rP1, a recently described member of the insulin-like growth factor-binding protein family was examined. IGFBP-rP1 is known to bind IGF-I and IGF-II and functions as a growth suppresser in several tissues $[43,44]$. Northern analysis indicated that IGFBP-rP1 expression remained constant during the oestrous cycle and was up to 1.8-fold up-regulated $(P<0.05)$ in day 17 regressed luteal tissue (Fig. 2). The upregulation of IGFBP-rP1 in late luteal tissue is consistent with its role as a cell growth inhibitor. At this time, luteal cells become replicatively quiescent, culminating in the ultimate demise of the CL. In addition, a recent study has also implicated IGFBP-rP1 as a suppressor of granulosa cell growth in porcine preovulatory follicles [45]. Although the precise mechanisms by which IGFBP-rP1 inhibits cellular growth still remain to be elucidated, it is tempting to speculate that up-regulation of IGFBP-rP1 antagonises the effects of IGF-I, thereby impairing luteal growth and contributing to CL regression. It is also possible that these events are mediated independently of the IGF system as outlined previously [46].

\section{Conclusion}

The molecular mechanisms regulating the development, maintenance and regression of the CL are complex and not fully understood. This problem is compounded by the limited number of annotated CL nucleotide sequences currently deposited in the public databases $(<140)$. Although this EST survey is relatively small, the characterisation of 351 unique ESTs represents an important initial assessment of genes active in the CL. Many of the identified ESTs encode proteins linked to specific aspects of CL function including, angiogenesis, extracellular matrix remodelling, lipid/steroid biosynthesis and apoptosis. In 
addition, a number of ESTs encode genes involved in transcriptional regulation and cell signalling, many of which have not previously been identified in CL tissue. A large percentage $(25 \%)$ of the unique CL ESTs correspond to uncharacterised protein, nucleotide and EST sequences, some of which were abundantly expressed and may therefore play an important role in primary CL function. Expression studies have provided new insights into the potential role of squalene epoxidase and IGFBP-rP1 in steroidogenesis and in CL regression, respectively. The ESTs generated in this study now permit the construction of cDNA arrays facilitating further functional analysis of CL gene expression and the underlying causes of luteal insufficiency which impairs animal reproductive efficiency.

\section{Acknowledgements}

One of the authors of this paper, Dr. Richard Powell, died suddenly during the course of this study. We would like to acknowledge Richie's essential contribution to this work and to pay tribute to his great love and enthusiasm for science which drove him and inspired those who worked with him. He is sadly missed.

O.M.C. is currently supported by the Teagasc Walsh postgraduate fellowship scheme.

\section{References}

[1] W. Hansel, R.M. Blair, Bovine corpus luteum: a historic overview and implications for future research, Theriogenology 45 (1996) $1267-1294$.

[2] M.J. Fields, P.A. Fields, Morphological characteristics of the bovine corpus luteum during the estrous cycle and pregnancy, Theriogenology 45 (1996) 1295-1325.

[3] L.P. Reynolds, D.A. Redmer, Growth and development of the corpus luteum, J. Reprod. Fertil. Suppl. 54 (1999) 181-191.

[4] F.J. Diaz, L.E. Anderson, Y.L. Wu, A. Rabot, S.J. Tsai, M.C. Wiltbank, Regulation of progesterone and prostaglandin F2alpha production in the CL, Mol. Cell. Endocrinol. 191 (2002) 65-80.

[5] R.A. Milvae, S.T. Hinckley, J.C. Carlson, Luteotropic and luteolytic mechanisms in the bovine corpus luteum, Theriogenology 45 (1996) $1327-1349$.

[6] J.L. Pate, Cellular components involved in luteolysis, J. Anim. Sci. 72 (1994) $1884-1890$.

[7] R. Webb, K.J. Woad, D.G. Armstrong, Corpus luteum (CL) function: local control mechanisms, Domest. Anim. Endocrinol. 23 (2002) $277-285$.

[8] J.L. Juengel, G.D. Niswender, Molecular regulation of luteal progesterone synthesis in domestic ruminants, J. Reprod. Fertil. Suppl. 54 (1999) $193-205$.

[9] A.J. Reinhart, S.C. Williams, D.M. Stocco, Transcriptional regulation of the StAR gene, Mol. Cell. Endocrinol. 151 (1999) 161-169.

[10] J.E. Garrett, R.D. Geisert, M.T. Zavy, G.L. Morgan, Evidence for maternal regulation of early conceptus growth and development in beef cattle, J. Reprod. Fertil. 84 (1988) 437-446.

[11] G.R. Starbuck, A.O. Darwash, G.E. Mann, G.E. Lamming, The detection and treatment of post insemination progesterone insufficiency in dairy cows, BSAS Occas. Publ. 26 (2001) 447-450.

[12] W.R. Butler, J.J. Calaman, S.W. Beam, Plasma and milk urea nitrogen in relation to pregnancy rate in lactating dairy cattle, J. Anim. Sci. 74 (1996) $858-865$.

[13] M.D. Adams, J.M. Kelley, J.D. Gocayne, M. Dubnick, M.H. Polymeropoulos, H. Xiao, C.R. Merril, A. Wu, B. Olde, R.F. Moreno, et al., Complementary DNA sequencing: expressed sequence tags and human genome project, Science 252 (1991) 1651-1656.

[14] R.Z. Ma, M.J. van Eijk, J.E. Beever, G. Guerin, C.L. Mummery, H.A. Lewin, Comparative analysis of 82 expressed sequence tags from a cattle ovary cDNA library, Mamm. Genome 9 (1998) 545-549.

[15] T.S. Sonstegard, A.V. Capuco, J. White, C.P. Van Tassell, E.E. Connor, J. Cho, R. Sultana, L. Shade, J.E. Wray, K.D. Wells, J. Quackenbush, Analysis of bovine mammary gland EST and functional annotation of the Bos taurus gene index, Mamm. Genome 13 (2002) 373-379.

[16] S. Ponsuksili, K. Wimmers, J. Adjaye, K. Schellander, A source for expression profiling in single preimplantation bovine embryos, Theriogenology 57 (2002) 1611-1624.

[17] Y. Taniguchi, H.Y. Lejukole, T. Yamada, S. Akagi, S. Takahashi, M. Shimizu, H. Yasue, Y. Sasaki, Analysis of expressed sequence tags from a cDNA library of somatic nuclear transfer-derived cloned bovine whole foetus, Anim. Genet. 32 (2001) 1-6.

[18] T.P. Smith, W.M. Grosse, B.A. Freking, A.J. Roberts, R.T. Stone, E. Casas, J.E. Wray, J. White, J. Cho, S.C. Fahrenkrug, G.L. Bennett, M.P. Heaton, W.W. Laegreid, G.A. Rohrer, C.G. Chitko-McKown, G. Pertea, I. Holt, S. Karamycheva, F. Liang, J. Quackenbush, J.W. Keele, Sequence evaluation of four pooled-tissue normalized bovine cDNA libraries and construction of a gene index for cattle, Genome Res. 11 (2001) 626-630.

[19] T. Bonsdorff, A. Eggen, M. Gautier, H.C. Asheim, K. Ronningen, F. Lingaas, I. Olsaker, Identification and physical mapping of genes expressed in the corpus luteum in cattle, Anim. Genet. 34 (2003) $325-333$.

[20] M.R. Band, C. Olmstead, R.E. Everts, Z.L. Liu, H.A. Lewin, A 3800 gene microarray for cattle functional genomics: comparison of gene expression in spleen, placenta, and brain, Anim. Biotechnol. 13 (2002) 163-172.

[21] H. Ishiwata, S. Katsuma, K. Kizaki, O.V. Patel, H. Nakano, T. Takahashi, K. Imai, A. Hirasawa, S. Shiojima, H. Ikawa, Y. Suzuki, G. Tsujimoto, Y. Izaike, J. Todoroki, K. Hashizume, Characterization of gene expression profiles in early bovine pregnancy using a custom cDNA microarray, Mol. Reprod. Dev. 65 (2003) 9-18.

[22] U. Dorroch, T. Goldammer, R.M. Brunner, S.R. Kata, C. Kuhn, J.E. Womack, M. Schwerin, Isolation and characterization of hepatic and intestinal expressed sequence tags potentially involved in trait differentiation between cows of different metabolic type, Mamm. Genome 12 (2001) 528-537.

[23] C. Looft, N. Reinsch, C. Karall-Albrecht, S. Paul, M. Brink, H. Thomsen, G. Brockmann, C. Kuhn, M. Schwerin, E. Kalm, A mammary gland EST showing linkage disequilibrium to a milk production QTL on bovine Chromosome 14, Mamm. Genome 12 (2001) $646-650$.

[24] J. Sambrook, E.F. Fritsch, T. Maniatis (Eds.), Molecular Cloning: A Laboratory Manual, Cold Spring Harbor Laboratory Press, Cold Spring Harbor, NY, 1990.

[25] G.C. Davey, N.C. Caplice, S.A. Martin, R. Powell, A survey of genes in the Atlantic salmon (Salmo salar) as identified by expressed sequence tags, Gene 263 (2001) 121-130.

[26] S.F. Altschul, W. Gish, W. Miller, E.W. Myers, D.J. Lipman, Basic local alignment search tool, J. Mol. Biol. 215 (1990) 403-410.

[27] J.J. Ireland, R.L. Murphee, P.B. Coulson, Accuracy of predicting stages of bovine estrous cycle by gross appearance of the corpus luteum, J. Dairy Sci. 63 (1980) 155-160.

[28] SAS/STAT ${ }^{\mathrm{TM}}$ Users Guide, 8.1 ed., Statistical Analysis Systems Institute, Cary, NC, 2001.

[29] M.B. Dworkin, I.B. Dawid, Use of a cloned library for the study of abundant poly(A)+ RNA during Xenopus laevis development, Dev. Biol. 76 (1980) 449-464. 
[30] P.S. Nelson, V. Hawkins, M. Schummer, R. Bumgarner, W.L. Ng, T. Ideker, C. Ferguson, L. Hood, Negative selection: a method for obtaining low-abundance cDNAs using high-density cDNA clone arrays, Genet. Anal. 15 (1999) 209-215.

[31] C.T. Lin, D.R. Sargan, Generation and analysis of canine retinal ESTs: isolation and expression of retina-specific gene transcripts, Biochem. Biophys. Res. Commun. 282 (2001) 394-403.

[32] S.A. Martin, N.C. Caplice, G.C. Davey, R. Powell, EST-based identification of genes expressed in the liver of adult Atlantic salmon (Salmo salar), Biochem. Biophys. Res. Commun. 293 (2002) 578-585.

[33] F.W. Bazer (Ed.), The Endocrinology of Pregnancy, Humana Press, Totowa, NJ, 1998, pp. 177-197.

[34] M.D. Adams, A.R. Kerlavage, R.D. Fleischmann, R.A. Fuldner, C.J. Bult, N.H. Lee, E.F. Kirkness, K.G. Weinstock, J.D. Gocayne, O. White, et al., Initial assessment of human gene diversity and expression patterns based upon 83 million nucleotides of cDNA sequence, Nature 377 (1995) 3-174.

[35] G.D. Niswender, J.L. Juengel, P.J. Silva, M.K. Rollyson, E.W. McIntush, Mechanisms controlling the function and lifespan of the corpus luteum, Physiol. Rev. 80 (2000) 1-29.

[36] M. Lutz, L.J. Burke, G. Barreto, F. Goeman, H. Greb, R. Arnold, H. Schultheiss, A. Brehm, T. Kouzarides, V. Lobanenkov, R. Renkawitz, Transcriptional repression by the insulator protein CTCF involves histone deacetylases, Nucleic Acids Res. 28 (2000) 1707-1713.

[37] J.L. Juengel, H.A. Garverick, A.L. Johnson, R.S. Youngquist, M.F. Smith, Apoptosis during luteal regression in cattle, Endocrinology 132 (1993) 249-254

[38] I. Wittke, B. Madge, R. Wiedemeyer, A. Kimchi, M. Schwab, DAP-5 is involved in MycN/IFNgamma-induced apoptosis in human neuroblastoma cells, Cancer Lett. 162 (2001) 237-243.
[39] K. Komatsu, N. Manabe, M. Kiso, M. Shimabe, H. Miyamoto, Changes in localization of immune cells and cytokines in corpora lutea during luteolysis in murine ovaries, J. Exp. Zool., Suppl. 296 (2003) $152-159$

[40] T. Ono, The first step of oxygenation in cholesterol biosynthesis, Biochem. Biophys. Res. Commun. 292 (2002) 1283-1288.

[41] M.C. Johnson, L. Devoto, I. Retamales, P. Kohen, J.L. Troncoso, G. Aguilera, Localization of insulin-like growth factor (IGF-I) and IGF-I receptor expression in human corpora lutea: role on estradiol secretion, Fertil. Steril. 65 (1996) 489-494.

[42] H.M. Fraser, S.F. Lunn, H. Kim, W.C. Duncan, F.E. Rodger, P.J. Illingworth, G.F. Erickson, Changes in insulin-like growth factorbinding protein-3 messenger ribonucleic acid in endothelial cells of the human corpus luteum: a possible role in luteal development and rescue, J. Clin. Endocrinol. Metab. 85 (2000) 1672-1677.

[43] Y. Oh, S.R. Nagalla, Y. Yamanaka, H.S. Kim, E. Wilson, R.G. Rosenfeld, Synthesis and characterization of insulin-like growth factor-binding protein (IGFBP)-7. Recombinant human mac25 protein specifically binds IGF-I and -II, J. Biol. Chem. 271 (1996) 30322-30325

[44] V. Hwa, Y. Oh, R.G. Rosenfeld, The insulin-like growth factor-binding protein (IGFBP) superfamily, Endocr. Rev. 20 (1999) 761-787.

[45] S.A. Wandji, J.E. Gadsby, J.A. Barber, J.M. Hammond, Messenger ribonucleic acids for MAC25 and connective tissue growth factor (CTGF) are inversely regulated during folliculogenesis and early luteogenesis, Endocrinology 141 (2000) 2648-2657.

[46] C.C. Sprenger, S.E. Damon, V. Hwa, R.G. Rosenfeld, S.R. Plymate, Insulin-like growth factor binding protein-related protein 1 (IGFBP$\mathrm{rP} 1)$ is a potential tumor suppressor protein for prostate cancer, Cancer Res. 59 (1999) 2370-2375. 